\title{
Preferred pH of silver catfish Rhamdia quelen acclimated to different pH levels
}

\author{
pH preferencial em jundiás Rhamdia quelen aclimatados em diferentes níveis de pH
}

\author{
Ana Paula Konzen Riffel ${ }^{I}$ Sinara Jardim ${ }^{\mathrm{I}}$ Marcela Ciprandi Pires ${ }^{\mathrm{I}}$ Bruna Bertagnolli $^{\mathrm{I}}$ \\ Bruna Renata Silva Corrêa ${ }^{I}$ Francine Cenzi de Ré ${ }^{I}$ Francis Maria Bao Zambra ${ }^{\mathrm{I}}$ Greice Lubini $^{\mathrm{I}}$ \\ Luciano Oliveira Garcia ${ }^{\text {II }}$ Bernardo Baldisserotto ${ }^{\text {I*,III }}$
}

\begin{abstract}
The aim of this study was to investigate the preferred $\mathrm{pH}$ in silver catfish Rhamdia quelen acclimated to different $p H$. Fish were acclimated for one week at $p H 4.2 \pm 0.1,5.2 \pm 0.1$, $6.3 \pm 0.1,7.2 \pm 0.1,8.0 \pm 0.1$, and $9.0 \pm 0.1$ and after this period, transferred to a polyethylene tube with a $\mathrm{pH}$ gradient from 3.5 to 10.0. The position of the fish in the $\mathrm{pH}$ gradient was observed 1,6 and 12 hours after transference. Results indicated that acclimation to different $\mathrm{pH}$ did not change $\mathrm{pH}$ preference of silver catfish ( $p H$ 7.0-7.6), occurring only a transitory variation around 6 hours after transference. This $\mathrm{pH}$ preference coincides with the best $\mathrm{pH}$ indicated in the literature for growth of this species.
\end{abstract}

- NOTE -
Key words: $p H$ preference, water quality, behavior.

RESUMO

O objetivo deste estudo foi verificar o $\mathrm{pH}$ preferencial de jundiás Rhamdia quelen aclimatados em diferentes $\mathrm{pH}$. Os jundiás foram aclimatados por uma semana em $p H 4,2 \pm 0,1 ; 5,2 \pm 0,1 ; 6,3 \pm 0,1 ; 7,2 \pm 0,1 ; 8,0 \pm 0,1$ e $9,0 \pm 0,1$ $e$, após esse período, transferidos para um tubo de polietileno com $\mathrm{pH}$ variando entre 3,5 e 10 . A posição dos exemplares no gradiente de pH foi observada 1, 6 e 12 horas após a transferência. Os resultados indicam que a aclimatação em diferentes $p H$ não altera o $\mathrm{pH}$ preferencial dos peixes ( $\mathrm{pH}$ 7.07.6), ocorrendo apenas uma variação transitória em torno de 6 horas após a transferência. Este pH preferencial coincide com o pH indicado na literatura como o melhor para o crescimento desta espécie.

\begin{abstract}
Palavras-chave: $p H$ preferencial, qualidade da água, comportamento.
\end{abstract}

Abiotic factors such as light, temperature, oxygen, and water quality parameters as $\mathrm{pH}$ can change physiological, biochemical and behavioral responses of fishes. The effect of environmental variables on movement of aquatic organisms can be examined using preference and avoidance behaviors (KROON \& HOUSEFIELD, 2003). Water $\mathrm{pH}$ is usually regulated by the carbonate - bicarbonate system, generally remaining between 6.0 and 8.0. Oscillations in $\mathrm{pH}$ levels can occur in fish culture tanks or in the environment due to the soil composition, acid rain, phytoplankton, presence of humic substances, and other factors (BALDISSEROTTO, 2011). Acidic pH can damage gills, resulting in ionic imbalance while alkaline $\mathrm{pH}$ impairs ammonia excretion (BALDISSEROTTO, 2011), increasing its plasma levels, which can lead to death (SCOTT et al., 2005).

The silver catfish Rhamdia quelen has neotropical distribution and therefore can be exposed to a wide $\mathrm{pH}$ range (BALDISSEROTTO, 2009). This species tolerates $\mathrm{pH}$ between 4.0 and 9.0 (ZAIONS \& BALDISSEROTTO, 2000) and juveniles presented better growth at $\mathrm{pH}$ 7.0-7.5 than at $\mathrm{pH} 5.5$ and 9.0

\footnotetext{
'Departamento de Fisiologia e Farmacologia, Universidade Federal de Santa Maria (UFSM), 97105-900, Santa Maria, RS, Brasil. E-mail: bbaldisserotto@hotmail.com.*Autor para correspondência.

"Instituto de Oceanografia, Estação Marinha de Aquacultura (EMA), Universidade Federal do Rio Grande (FURG), Rio Grande, RS, Brasil.

IIIPrograma de Pós-graduação em Zootecnia, UFSM, Santa Maria, RS, Brasil.
} 
(BALDISSEROTTO, 2011). Most studies related to extreme $\mathrm{pH}$ refer to the lethality. Although there are many studies investigating the behavior of fish in relation to environmental factors and water quality, studies relating effects of water $\mathrm{pH}$ and behavior are scarce (JONES et al., 1985; IKUTA et al., 2003; SCOTT et al., 2005) and nonexistent in Brazilian native species. Therefore, the objective of this study was to evaluate silver catfish preferred $\mathrm{pH}$.

Juveniles $(10 \pm 4 \mathrm{~g})$ were obtained from a local fish farm and acclimated to laboratory conditions $\left(23 \pm 01^{\circ} \mathrm{C}\right)$ for 20 days. Photoperiod was $12 \mathrm{~h}$ light- $12 \mathrm{~h}$ darkness, and the luminosity of the laboratory was 0.6 lux (measured with a LI-COR photometer model LI185B). Fish were then divided in groups and kept for seven days in continuously aerated 40L aquaria with different $\mathrm{pH}$ : $4.2 \pm 0.1,5.2 \pm 0.1,6.3 \pm 0.1,7.2 \pm 0.1,8.0 \pm 0.1$, and 9.0 \pm 0.1 . Juveniles were fed once a day, at 8:00 a.m. Uneaten food, as well as other residues and feces were siphoned 30 min after furnishing the food, and consequently at least $20 \%$ of the water was replaced with water previously adjusted to the appropriate $\mathrm{pH}$ using $\mathrm{NaOH}$ or $\mathrm{H}_{2} \mathrm{SO}_{4} 0.5 \mathrm{M}$. After this period, each group was transferred to a $6 \mathrm{~m}$ long polyethylene tube containing 50L of water, which had been added at one end $1 \mathrm{~N}$ sulfuric acid to generate $\mathrm{pH}$ around 3.5 and, in the other end $1 \mathrm{~N}$ sodium hydroxide was added to obtain $\mathrm{pH}$ around 10 . The reagents added at the extremities diffused through the water along the tube, creating the $\mathrm{pH}$ gradient, which was maintained with addition more of the same reagents at the extremities every two hours if necessary.

Each group (three replicates per treatment, $\mathrm{N}=10$ each) was placed in the tube region closest to its acclimation $\mathrm{pH}$. Fish location at the $\mathrm{pH}$ gradient was visually observed 1, 6 and 12 hours after the transfer, in order to identify their preferred $\mathrm{pH}$. The $\mathrm{pH}$ was always measured at the location at the moment of the observation. After 12 hours observation the water of the tube was exchanged and a new replicate was placed in tube.
Aerators were placed at the two ends of the tube, and oxygen monitored with oxygen meter YSI(Y5512) every 4 hours. The Ethics and Care Committee for Laboratory Animals of Federal University of Santa Maria (UFSM) agreed with the study protocol (2007-24).

The data obtained were analyzed with the Kruskal-Wallis test followed by Dunn test using the GraphPad Instat Software and reported as mean \pm S.E.M. The minimum significance level was set at $95 \%(\mathrm{P}<0.05)$.

Results indicate that silver catfish tended to settle in a neutral $\mathrm{pH}$ irrespective of acclimation $\mathrm{pH}$. The exception was the group acclimated at $\mathrm{pH} 8.0$ that 6 hours after the transference preferred a more alkaline $\mathrm{pH}$ compared to groups acclimated to $\mathrm{pH} 5.2$ and 7.2. This different preference was transitory, and in the other times observed there was no significant difference between groups (Table 1).

Sockeye salmon (Oncorhynchus nerka), brown trout (Salmo trutta) and Japanese trout (Salvelinus leucomaenis) showed inhibition of digging and swimming behavior against the flow in water slightly acidic (5.8-6.4) compared to neutral pH (6.87.1) (IKUTA et al., 2003). Juvenile brook trout (Salvelinus fontinalis) were given the choice of untreated ( $\mathrm{pH} 7.4$ ) or decarbonated acidic waters at varying $\mathrm{pH}$ levels (4.0, 5.0, 5.5, and 6.0) for 96 hours. Significant avoidance did not occur at neutral $\mathrm{pH}$ levels. Brook trout avoided $\mathrm{pH}$ 4.0, 5.0 and 5.5. The authors also observed that lower $\mathrm{pH}$ affected social interactions in this species (PEDDER \& MALY, 1986). Consequently, these species showed preference to a $\mathrm{pH}$ range near neutrality, as observed in the present experiment with silver catfish.

However, in other experiment brown trout juveniles demonstrated attraction to low $\mathrm{pH}$ (4.0, 4.5 and 5.0) compared to neutral pH ( $\AA$ TLAND, 1998). In addition, stickleback (Gasterosteus aculeatus) maintained in laboratory avoided water at $\mathrm{pH} 5.4$, which was slightly above the lethal level of 4.8-5.0, and showed a vague negative reaction to $\mathrm{pH} 5.8$, when the

Table 1 - pH adaptation of Rhamdia quelen juveniles and pH preferred 1, 6 and 12 hours after the transfer. Different letters indicate significant difference compared to the groups observed at the same time.

\begin{tabular}{cccc}
\hline & & & \\
& & & \\
Adaptation & $1 \mathrm{~h}$ & $6 \mathrm{~h}$ & $12 \mathrm{~h}$ \\
\hline $4.21 \pm 0.09$ & $7.46 \pm 0.06^{\mathrm{a}}$ & $7.41 \pm 0.08^{\mathrm{ab}}$ & $7.38 \pm 0.04^{\mathrm{a}}$ \\
$5.23 \pm 0.13$ & $7.33 \pm 0.14^{\mathrm{a}}$ & $7.05 \pm 0.18^{\mathrm{a}}$ & $7.03 \pm 0.18^{\mathrm{a}}$ \\
$6.35 \pm 0.12$ & $7.56 \pm 0.16^{\mathrm{a}}$ & $7.29 \pm 0.07^{\mathrm{ab}}$ & $7.28 \pm 0.02^{\mathrm{a}}$ \\
$7.20 \pm 0.05$ & $6.85 \pm 0.09^{\mathrm{a}}$ & $7.09 \pm 0.13^{\mathrm{a}}$ & $7.44 \pm 0.10^{\mathrm{a}}$ \\
$8.02 \pm 0.06$ & $7.54 \pm 0.15^{\mathrm{a}}$ & $8.40 \pm 0.37^{\mathrm{b}}$ & $7.6 \pm 0.12^{\mathrm{a}}$ \\
$9.00 \pm 0.10$ & $7.42 \pm 0.30^{\mathrm{a}}$ & $7.71 \pm 0.16^{\mathrm{ab}}$ & $7.48 \pm 0.49^{\mathrm{a}}$ \\
\hline
\end{tabular}


alternative choice was water at $\mathrm{pH}$ 6.8. In addition, stickleback avoided solutions of sodium hydroxide with $\mathrm{pH}$ above 11.0 . The $\mathrm{pH}$ range $7.0-11.0$ produced no avoidance response from this species given the choice between water at $\mathrm{pH} 6.8$ and the experimental solutions (JONES, 1948). Common carp (Cyprinus carpio) and goldfish (Carassius auratus) avoided $\mathrm{pH}$ values in the range 5.5-7.0 with preference values of 8.4 and 7.2, respectively. The avoidance of alkaline water for these species is $\mathrm{pH} 9.3$ for common carp and 8.6 for goldfish (ISHIO, 1965).

Fish populations from a slightly acidic lake (pH 6.4-6.6) and from an slightly alkaline lake (pH 8.48.6) placed in a gradient tank where there was a choice between these two waters, the fish from the acidic lake preferred the acidic water and those from alkaline lake, the alkaline water (ALABASTER \& LLOYD, 1984). So, it is believed that the long time of maintenance of fish at different $\mathrm{pH}$ may influence its $\mathrm{pH}$ preference, and it is possible that the time of acclimation in the present experiment (20 days) was not long enough to alter permanently silver catfish preference.

In conclusion, silver catfish juveniles preferred neutral $\mathrm{pH}$ irrespective of acclimation $\mathrm{pH}$, probably to avoid disturbances in homeostasis occasioned by alterations in hydrogen-ion concentration. Furthermore, the described methodology can contribute in the evaluation of other abiotic factors preferences in aquatic species.

\section{ACKNOWLEDGEMENTS}

Authors are grateful to Comissão de Aperfeiçoamento de Pessoal de Nível Superior (CAPES) and Conselho Nacional de Desenvolvimento Científico e Tecnológico (CNPq).

\section{REFERENCES}

ALABASTER, J.S.; LLOYD, R. Water quality criteria for freshwater fish. Cambridge: Great Britain at the University, 1984. 361p.

ÅTLAND, A. Behavioral responses of brown trout, Salmo trutta, juveniles in concentration gradients of $\mathrm{pH}$ and $\mathrm{Al}-\mathrm{a}$ laboratory study. Environmental Biology of Fishes, v.53, p.331-345, 1998. Available from: <http:// www.springerlink.com/content/k0r31u5p0227 x5x7/>. Accessed: Apr. 16, 2011. doi:10.1023/A:1007449717038.

BALDISSEROTTO, B. Piscicultura continental no Rio Grande do Sul: situação atual, problemas e perspectivas para o futuro. Ciência Rural, v.39, n.1, p.291-299, 2009. Available from: <http://www.scielo.br/pdf/cr/v39n1/a46cr443.pdf>. Accessed: 21 Dec. 21, 2010 . doi: 10.1590/S0103-84782008005000046.
BALDISSEROTTO, B. Water $\mathrm{pH}$ and hardness affect growth of freshwater teleosts. Brazilian Journal of Animal Science, v.40, p.138-144, 2011. Available from: <http:// www.revista.sbz.org.br/artigo/visualizar.php?artigo=66268 $>$. Accessed: Dec. 22, 2011.

IKUTA, K. et al. Effects of low pH on the reproductive behavior of salmonid fishes. Fish Physiology and Biochemistry, v.28, p.407-410, 2003. Available from: <http:// www.springerlink.com/content/u3821604m077h717/ fulltext.pdf $>$. Accessed: Dec. 22, 2010. doi:_10.1023/ B:FISH.0000030607.75565.74.

ISHIO, S. Behavior of fish exposed to toxic substances. Proceedings International Conference on Intelligent Systems for Molecular Biology, v.1, p.19-40, 1965.

JONES, J.R.E. A further study of the reactions of fish to toxic solutions. Journal of Experimental Biology, v.25, p.2234, 1948. Available from: <http://jeb.biologists.org/content/ 25/1/22>. Accessed: Dec. 19, 2011.

JONES, K.A. et al. Behavioral modifications in Arctic char (Salvelinus alpinus) chronically exposed to sublethal $\mathrm{pH}$. Physiological Zoology, v.58, p.400-412, 1985. Available from: <http://www.jstor.org/pss/30156015>. Accessed: Apr. 15, 2011.

KROON, F.J.; HOUSEFIELD, G.P. A fluviarium with controlled water quality for preference - avoidance experiments with fish and invertebrates. Limnology and Oceanography: Methods, v.1, p.39-44, 2003. Available from: <http:// www.aslo.org/lomethods/free/2003/0039.pdf>. Accessed: Apr. 16, 2011.

SCOTT, D.M. et al. The effect of high $\mathrm{pH}$ on ion balance, nitrogen excretion and behaviour in freshwater fish from an eutrophic lake: a laboratory and field study. Aquatic Toxicology, v.73, p.31-43, 2005. Available from: <http:// w w w. sciencedirect. c o m/s cience ? _o b = MImg\&_imagekey=B6T4G-4FV358F-2-R\&_cdi=4974\&_user $=687358 \&$ \& pii $=$ S0 $166445 \mathrm{X} 0500072 \mathrm{X} \&$ \&origin $=$ se $\operatorname{arch}$ \&_coverDate $=06 \% 2$ F01\%2F2005\&_sk=999269998\& view $=c \& w c h p=d G L z V t b-z S k z S \& m d 5=4 b 6 a 515$ cec706eebe5dc 75ce1fe9c35c\&ie=/sdarticle.pdf $>$. Accessed: Dec. 21, 2010. doi: 10.1016/j.aquatox.2004.12.013.

PEDDER S.C.J.; MALY, E.J. The avoidance response of groups of juvenile brook trout, Salvelinus fontinallis, to varying levels of acidity. Aquatic Toxicology, v.8, p.111-119, 1986. Available from: <http://www.sciencedirect.com/science/article/pii/ 0166445X86900573>. Accessed: Dec. 21, 2011.

ZAIONS, M.I.; BALDISSEROTTO, B. $\mathrm{Na}^{+}$and $\mathrm{K}^{+}$body levels and survival of fingerlings of Rhamdia quelen (Siluriformes: Pimelodidae) exposed to acute changes of water $\mathrm{pH}$. Ciência Rural, v.30, p.1041-1045, 2000. Available from: <http:// www.scielo.br/pdf/cr/v30n6/a20v30n6.pdf>. Accessed: Dec. 21, 2010. doi: 10.1590/S0103-84782000000600020. 